\title{
The Floor of the Arctic Ocean in Photographs ${ }^{1}$
}

\author{
KENNETH HUNKINS, GUY MATHIEU, STEVEN TEETER \\ AND ALLAN GILL
}

\begin{abstract}
The floor of the Arctic Ocean in photographs. Over 2,000 usable bottom photographs have been taken in the western Arctic Ocean. The 87 stations cover the major geomorphic provinces of this part of the Arctic Basin, including the Alpha Cordillera, Mendeleyev Ridge, and Canada Abyssal Plain as well as smaller features. The ridge and plain provinces differ markedly in their bottom characteristics. Scattered rocks, living animals and indications of bottom current are most prevalent on the ridges. Trails are most abundant on the abyssal plains. The differences are attributed to bottom current distributions and turbidity currents. Bedrock outcrops were observed on the tops of two knolls on the Mendeleyev Ridge.
\end{abstract}

RÉSUMÉ. Le fond de l'océan Arctique en photographies. Dans la partie occidentale de l'océan Arctique, on a pris plus de 2,000 clichés du fond sous-marin. Les 87 stations couvrent les principales provinces géomorphologiques de cette partie du bassin arctique et comprennent la cordillère Alpha, la dorsale de Mendéléev et la plaine abyssale canadienne, ainsi que des reliefs de moindre importance. Les dorsales et la plaine abyssale diffèrent beaucoup dans leurs caractéristiques de fond. Sur les dorsales, des roches éparpillées, des animaux vivants et des indices de courants de fond dominent. Dans la plaine abyssale, les pistes d'animaux marins sont abondantes. On attribue ces différences à la distribution des courants de fond et aux courants de turbidité. On a observé des affleurements du soubassement sur le sommet de deux monticules de la dorsale de Mendéléev.

РЕЗЮМЕ. Фотограбби дна Северного Ледовитого океана. При съемках дна западной части Северного Једовитого океана было получено свыше 2000 фотографий удовлетворительного качества. Фотографии, снятые на 87 станциях, охватывают все основные геоморфологические провинции данной части Полярного бассейна, включая Кордильеры Альфа, хребет Менделеева, Канадскую абиссальную равнину, а также более мелкие структуры. Отмечены значительные различия в доннытх характеристиках хребтов и равнин. $\mathrm{Ha}$ фотографиях хребтов в основном преобладают обломки скальных пород, следы деятельности донных течений и морские животные, в то время как следы живых организмов особенно многочисленны на снимках равнинных участков. Отмеченные различия объясняются распределением донных течений и турбулентных потоков. Были зарегистрированы выходы коренных пород на двух вершинах хребта Менделеева.

\section{INTRODUCTION}

The ocean-bottom camera has been developed over the past 30 years at various oceanographic institutions as an instrument for use from research vessels. During that period, photography has become an important oceanographic tool, revealing

1Publication No. 1581 of the Lamont-Doherty Geological Observatory of Columbia University, Palisades, New York. 
many geological, biological and hydrodynamic features of the benthic environment. A survey of the development and achievements of deep-sea photography in the open oceans is found in Hersey (1967).

Bottom cameras designed for shipboard use are adaptable for work at drifting ice stations. The first Arctic Ocean bottom photographs were taken from Drifting Station Alpha in 1957 (Hunkins et al. 1960). Two deep stations on the Alpha Cordillera showed soft sediments marked by tracks and ice-rafted rocks. No indications of bottom currents, such as scour or ripple marks, were noted. Animal life was also sparse. Sediment clouds which had been stirred up by the camera were tracked to give a measure of current velocity. A speed of about $1 / 2 \mathrm{~cm} . / \mathrm{sec}$. was estimated.

In the following year, 30 bottom photographs were taken from the USS Burton Island on the continental slope and rise north of Alaska (Carsola et al. 1961). The pictures show an almost featureless sedimentary bottom with a few tracks and holes. Brittle stars and fan worms were noted but there was no evidence of ice-rafted rocks.

In 1959, 110 photographs were taken over the Chukchi Plateau, mostly at relatively shallow depths, from Drifting Station Charlie (Cromie 1961). Numbers of bryozoans, ophiuroids, holothurians, amphipods and sponges were seen. Trails and ice-rafted rocks were also abundant.

A bottom-photograph program, begun in 1963 on Fletcher's Ice Island (T-3), continues to the present. This paper reports highlights and conclusions from the T-3 program. T-3 drifts along with the pack ice under the influence of winds and currents in the clockwise gyre of the western Arctic Ocean. During the seven years that the photographic program has been operative, T-3 has drifted over $13,000 \mathrm{~km}$., passing over all major topographic features of the western Arctic Ocean. A few unusual photographs of animals resulting from this work have been described by Ewing et al. (1969).

The $35 \mathrm{~mm}$. multiple-exposure cameras used on T-3 were designed and con-



FIG. 1. Locations of Arctic Ocean bottom camera station taken from $\mathrm{T}-3$. Geomorphic province boundaries modified after Hunkins (1968). N.A.P. signifies Northwind Abyssal Plain. 
structed by $\mathrm{E}$. Thorndike $(1959,1963)$. The standard bottom camera used for almost all pictures discussed here takes an oblique picture from a height of $3 \mathrm{~m}$., covering a bottom area of about $6 \mathrm{~m} .{ }^{2}$. A weight hanging below the camera triggers the electronic flash at the correct distance above bottom. Twenty or thirty exposures are generally made at a station by repeated lowering and raising just off the bottom. The drift of the ice is usually sufficient to insure a fresh view in each successive exposure.

A total of 2,086 usable pictures have been made from T-3 at 87 stations with the standard bottom camera. The positions of the stations are plotted in Fig. 1, together with the boundaries of major geomorphic provinces. Province boundaries are based on a map by Hunkins (1968) with some modifications. The Arctic Ocean is crossed by 3 nearly parallel ridge systems which divide it into 4 separate basins. The photographs described here were all taken in the Canada Basin, westernmost of the basins, and on the Alpha-Mendeleyev Ridge system which separates this basin from the rest of the Arctic Ocean. Station coverage is relatively good within this region and includes the Canada Abyssal Plain, which forms the level floor of the Canada Basin, the Alpha Cordillera and Mendeleyev Ridge which together span the Arctic Ocean. Other features such as the Northwind Ridge, Northwind Abyssal Plain and the continental rise were also photographed. The ridge provinces and the plain provinces differ markedly in their bottom characteristics. The small-scale features encompassed in the few square metres of the bottom photographs show good correlation with the large-scale topography delineated by echo sounder and described in terms of geomorphic provinces. This is clearly evident in the statistical summary of bottom characteristics for the different provinces in Table 1.

TABLE 1. Summary of Features Observed in Bottom Camera Stations on Various Geomorphic Provinces in the Arctic Ocean.

\begin{tabular}{|c|c|c|c|c|c|c|c|c|c|c|c|c|c|c|}
\hline & \multicolumn{2}{|c|}{$\begin{array}{c}\text { Alpha } \\
\text { Cordillera }\end{array}$} & \multicolumn{2}{|c|}{$\begin{array}{l}\text { Mendeleyev } \\
\text { Ridge }\end{array}$} & \multicolumn{2}{|c|}{$\begin{array}{l}\text { Northwind } \\
\text { Ridge }\end{array}$} & \multicolumn{2}{|c|}{$\underset{\text { Abyssal Plain }}{\text { Canada }}$} & \multicolumn{2}{|c|}{$\begin{array}{l}\text { Northwind } \\
\text { Abyssal Plain }\end{array}$} & \multicolumn{2}{|c|}{$\begin{array}{l}\text { Mendeleyev } \\
\text { Plain }\end{array}$} & \multicolumn{2}{|c|}{$\begin{array}{c}\text { Canada } \\
\text { Cont. Rise }\end{array}$} \\
\hline & $\begin{array}{l}\text { No. } \\
\text { of } \\
\text { Stas. }\end{array}$ & $\begin{array}{l}\text { Avg. } \\
\text { depth }\end{array}$ & $\begin{array}{c}\text { No. } \\
\text { of } \\
\text { Stas. }\end{array}$ & $\begin{array}{l}\text { Avg. } \\
\text { depth }\end{array}$ & $\begin{array}{l}\text { No. } \\
\text { of } \\
\text { Stas. }\end{array}$ & $\begin{array}{l}\text { Avg. } \\
\text { depth }\end{array}$ & $\begin{array}{c}\text { No. } \\
\text { of } \\
\text { Stas. }\end{array}$ & $\begin{array}{l}\text { Avg. } \\
\text { depth }\end{array}$ & $\begin{array}{c}\text { No. } \\
\text { of } \\
\text { Stas. }\end{array}$ & $\begin{array}{l}\text { Avg. } \\
\text { depth }\end{array}$ & $\begin{array}{c}\text { No. } \\
\text { of } \\
\text { Stas. }\end{array}$ & $\begin{array}{l}\text { Avg. } \\
\text { depth }\end{array}$ & $\begin{array}{l}\text { No. } \\
\text { of } \\
\text { Stas. }\end{array}$ & $\begin{array}{l}\text { Avg. } \\
\text { depth }\end{array}$ \\
\hline $\begin{array}{l}\text { Scattered } \\
\text { rocks } \\
\text { present }\end{array}$ & 45 & 2332 & 5 & 1908 & 4 & 1594 & 1 & 3762 & 0 & - & 4 & 3238 & 0 & - \\
\hline $\begin{array}{c}\text { No scattered } \\
\text { rocks }\end{array}$ & 3 & 2897 & 3 & 2324 & 1 & 2164 & 16 & 3787 & 2 & 2092 & 2 & 3295 & 1 & 3628 \\
\hline $\begin{array}{l}\text { Trails } \\
\text { present } \\
\text { in all } \\
\text { frames }\end{array}$ & 0 & - & 1 & 2650 & 0 & - & 16 & 3787 & 2 & 2092 & 1 & 3270 & 1 & 3628 \\
\hline $\begin{array}{c}\text { Trails not } \\
\text { present } \\
\text { in all } \\
\text { frames }\end{array}$ & 48 & 2368 & 7 & 1981 & 5 & 1708 & 1 & 3759 & 0 & - & 5 & 3255 & 0 & - \\
\hline $\begin{array}{c}\text { Living } \\
\text { animais } \\
\text { present }\end{array}$ & 39 & 2365 & 7 & 2096 & 4 & 1594 & 6 & 3789 & 2 & 2092 & 6 & 3257 & 1 & 3628 \\
\hline $\begin{array}{l}\text { No living } \\
\text { animals }\end{array}$ & 9 & 2380 & 1 & 1843 & 1 & 2164 & 11 & 3783 & 0 & - & 0 & - & 0 & - \\
\hline
\end{tabular}



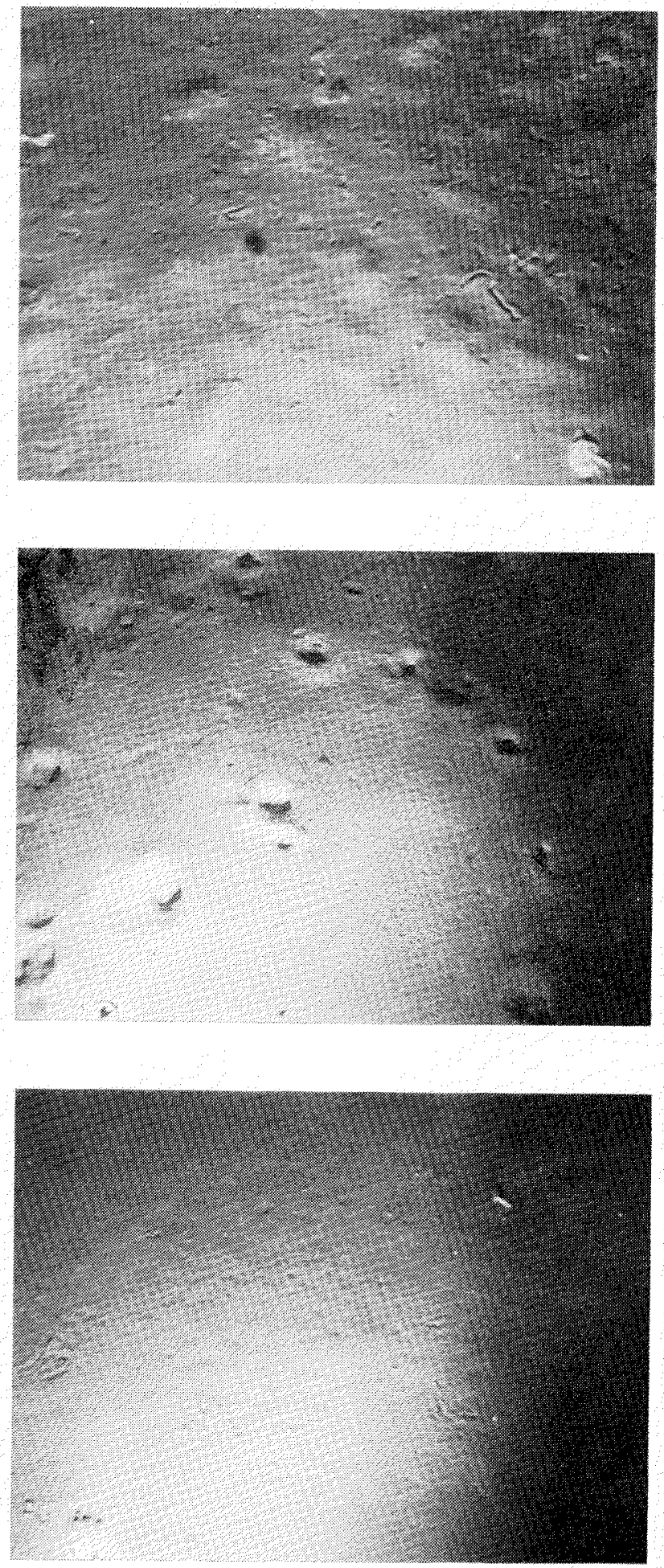

FIG. 2. Mounds, pits, tracks and grooves on the Alpha Cordillera. Amorphous white masses are probably fecal matter. Note brittle star near large groove. Sta. 63-2, 3,418 m., $83^{\circ} 03^{\prime} \mathrm{N} ., 163^{\circ} 31^{\prime} \mathrm{W}$.

FIG. 3. Deep pits of biological origin with elevated rims. Note tracks entering one hole.

Mendeleyev Ridge, Sta. $67-25,1,616 \mathrm{~m}$., $80^{\circ} 00^{\prime} \mathrm{N}$., $174^{\circ} 13^{\prime} \mathrm{W}$.

FIG. 4. Tracks and trails on soft bottom. Note holothurian at right. Mendeleyev Ridge, Sta. 67-15, 2,526 m., $79^{\circ} 35^{\prime} \mathrm{N}$., $171^{\circ} 34^{\prime} \mathrm{W}$. 


\section{RIDGES}

The Alpha Cordillera and Mendeleyev Ridge are $250 \mathrm{~km}$. to $800 \mathrm{~km}$. in width and 2,000 km. in combined length. They span the Arctic Ocean from the North American to the Eurasian continent. Their topography is rugged, being composed of mountain chains and isolated peaks rising up to $2,000 \mathrm{~m}$. above their bases. This ridge system is believed to be a former mid-oceanic ridge, now extinct, which once served as the locus for sea floor spreading in the Arctic (Beal 1968).

The soft bottom sediment on these ridges is generally smooth with gentle undulations. Various markings of biological origin and scattered rocks are noted. Examples of smoothed mud bottoms on the Alpha Cordillera with mounds, pits and grooves are shown in Fig. 2. Unidentified amorphous material, probably fecal matter from bottom feeders, can also be seen. Deeper pits with a characteristic elevated rim were noted on the Mendeleyev Ridge. Tracks can be seen entering one of the pits in Fig. 3. Continuous tracks or trails are not as universal on the ridge provinces as they are on the plain provinces. Table 1 shows that out of 61 stations on the ridges, only one, on the Mendeleyev Ridge, showed tracks or trails in all frames.

However, animals make an appearance fairly frequently on ridges, being observed in 50 of the 61 ridge stations. An example is the brittle star in Fig. 2. A holothurian or shrimp crawls along the bottom in Fig. 4 taken on the Mendeleyev Ridge. On the Northwind Ridge, a spur of the Chukchi Platform, a crinoid and worm tubes are attached to a rafted rock (Fig. 5). Small unidentified animals are present in Fig. 6. Stalked growths encrust the rock in the lower left and impressions of brittle stars are seen near the centre top. Many more brittle star markings as well as a live specimen occur on the crest of the Northwind Ridge (Fig. 7).

White spots speckle Fig. 5 as well as all other exposures at this station. The spots cannot be attributed to poor photographic technique and must represent highly reflective material either in the water or on the bottom. If they were due to suspended matter they would be distributed relatively uniformly throughout the field, yet they are more concentrated around the ice-rafted rock in the photograph. This suggests that they are organisms or light-coloured pebbles on the bottom and that they have been exposed by current scour around the large rock. The uniform size of the white specks supports organisms as the cause.

Erratic rocks which have been rafted out into the ocean on ice make frequent appearances in ridge photographs. They are present in 44 of the 47 stations taken on the Alpha Cordillera and may be topped by a cap of loose sediment (Fig. 8). Rocks similar to these have been dredged and described by Schwarzacher and Hunkins (1961). They concluded that the rocks were of glacial origin on the basis of striation, shape and roundness. Glacial tills, deposited when the ice islands were still part of the Ellesmere Ice Shelf, have been found on ice islands, T-3 and ARLIS II. Ice islands dump this material into the ocean during breakup, a situation which was actually observed in the case of ARLIS II. Little or no sediment is found on pack ice far from land and it appears that the ice islands rather than pack ice floes are the source of ice-rafted gravels on the Arctic Ocean 

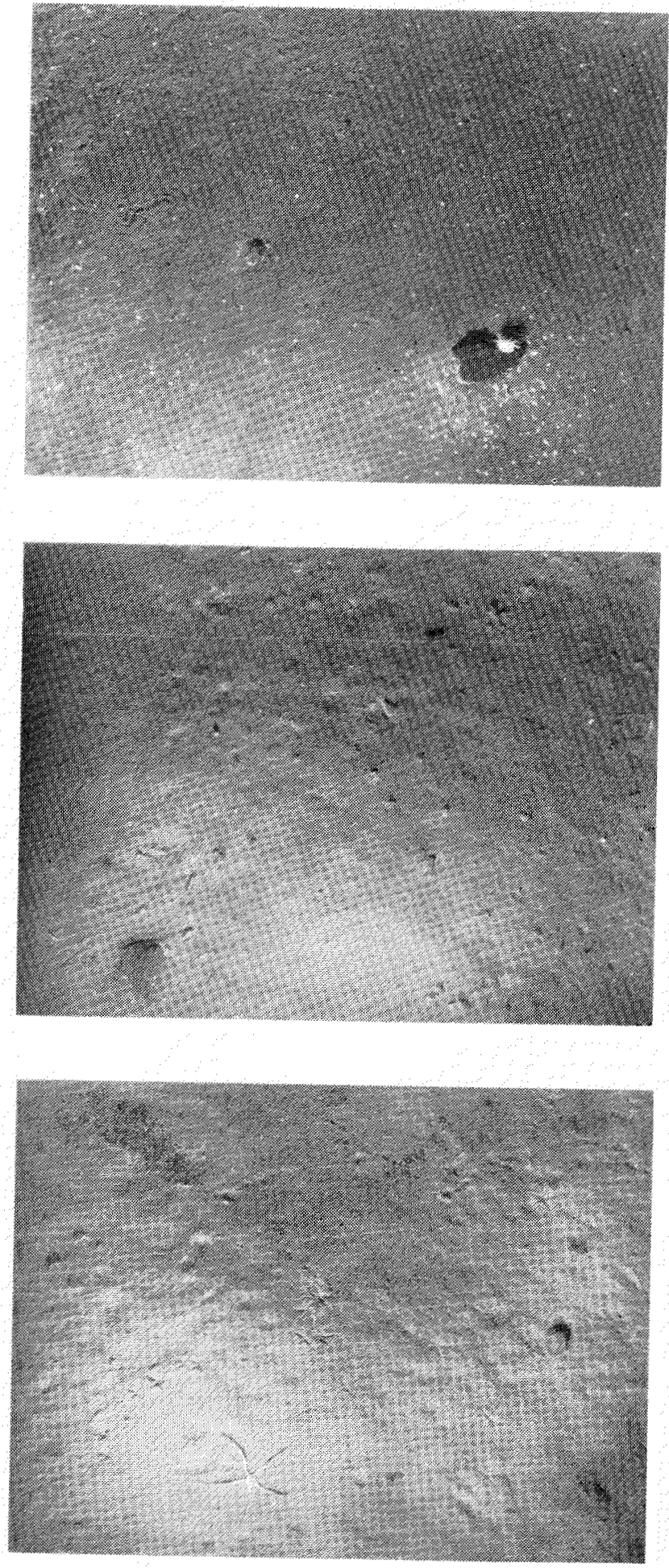

FIG. 5. Ice-rafted rock with crinoid attached. Note white unidentified specks on the bottom. Northwind Ridge, Sta. 66-11, 2,880 m., $75^{\circ} 25^{\prime} \mathrm{N} ., 155^{\circ} 55^{\prime} \mathrm{W}$.

FIG. 6. Small animals and rafted rocks near the crest of the Northwind Ridge. Note stalked growths on rock in lower left. A swimming animal near the centre is just off the bottom. Beyond are impressions left by brittle stars. Sta. 66-18, $911 \mathrm{~m}$., $75^{\circ} 40^{\prime} \mathrm{N}$., $157^{\circ} 36^{\prime} \mathrm{W}$.

FIG. 7. Brittle star and markings on the crest of the Northwind Ridge, Sta. 66-19, $613 \mathrm{~m}$., $75^{\circ} 48^{\prime} \mathrm{N}$., $158^{\circ} 25^{\prime} \mathrm{W}$. 

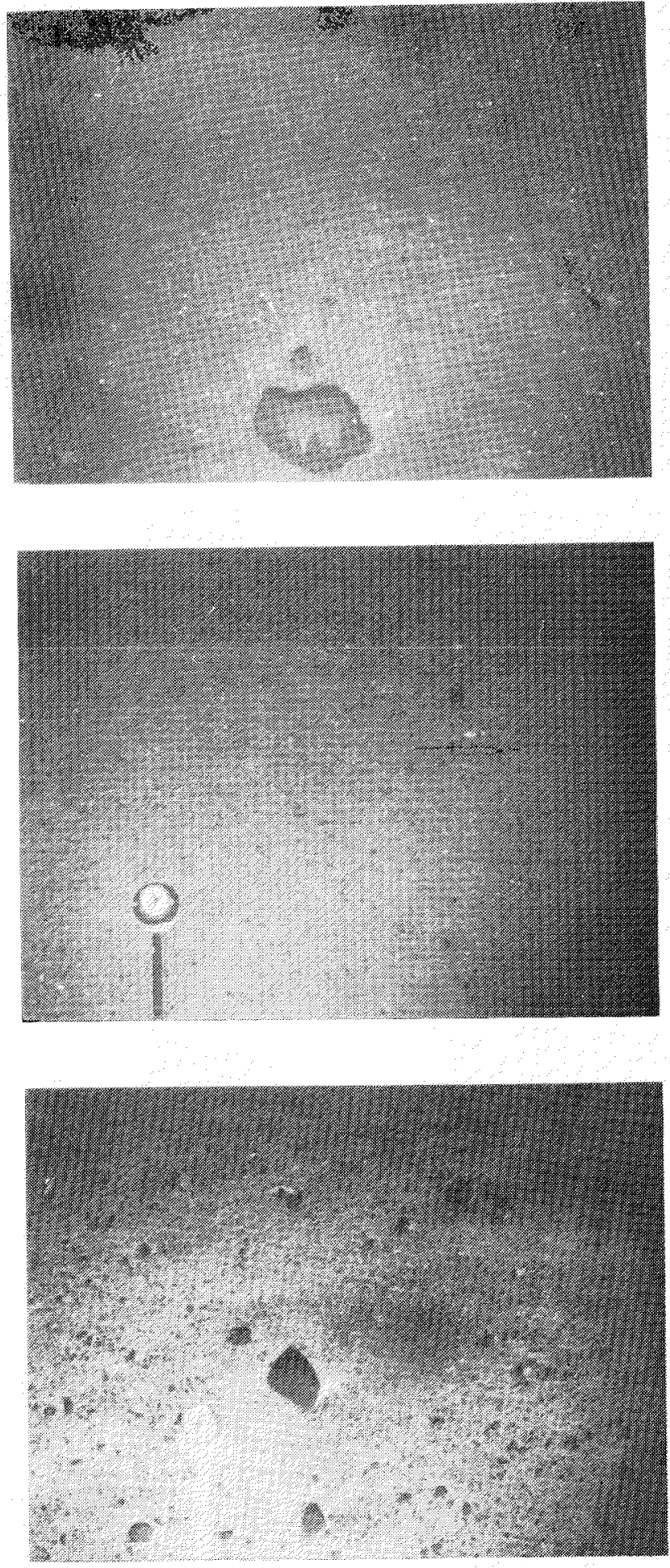

FIG. 8. Ice-rafted rock with cap of loose sediment. White specks are unidentified.

Sta. 66-11, 2,880 m., $75^{\circ} 25^{\prime} \mathrm{N}$., $155^{\circ} 55^{\prime} \mathrm{W}$.
FIG. 9. Closely packed gravel on the Alpha Cordillera. Sta. 68-52, $1,884 \mathrm{~m} ., 85^{\circ} 05^{\prime} \mathrm{N}$., $137^{\circ} 21^{\prime} \mathrm{W}$.
FIG 10. Scour on the Alpha Cordillera indicating moderate bottom currents setting northeast magnetic. Sta. 69-43, 1,461 m., $84^{\circ} 59^{\prime}$ N., $126^{\circ} 00^{\prime} \mathrm{W}$. 


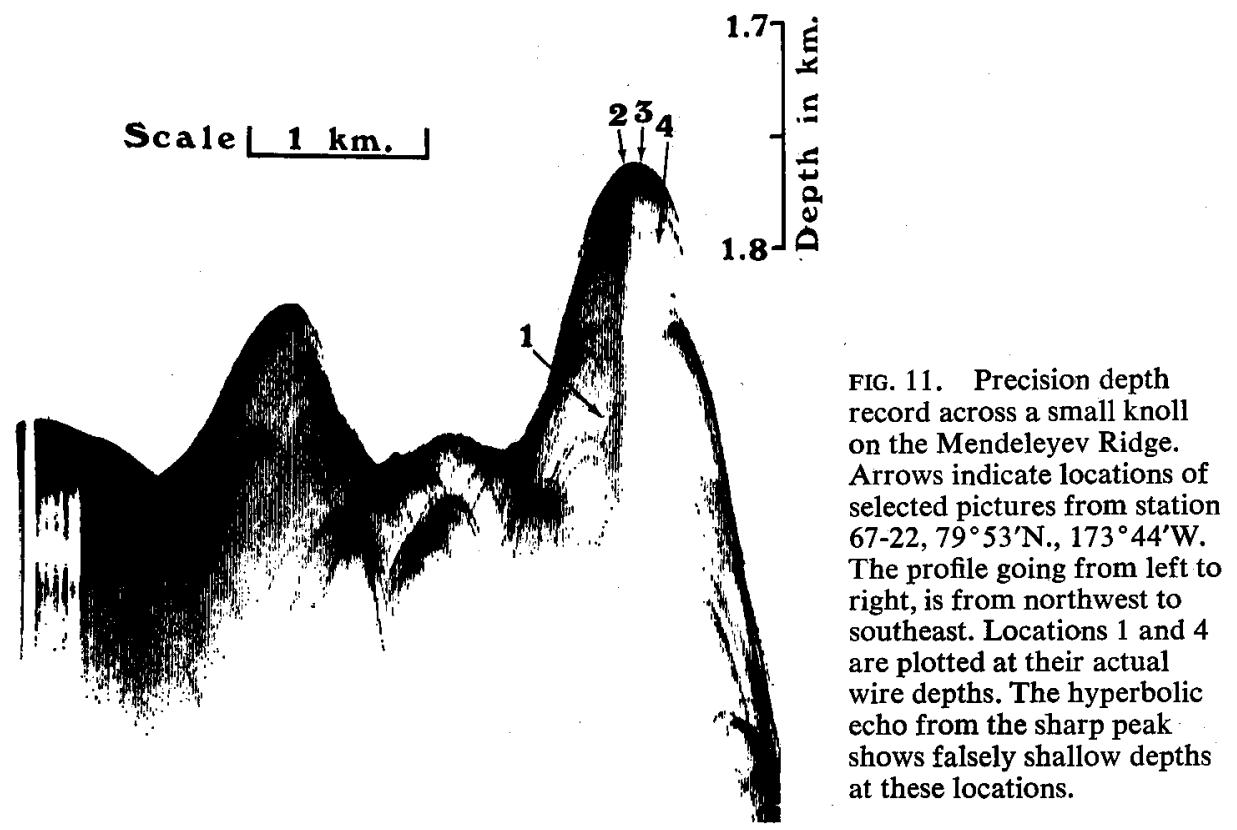

floor. Most of the dredged gravels are coated with a thin layer of manganese which probably accounts for the dark appearance of rocks in the photographs.

Evidence of bottom currents appears clearly in a number of photographs taken on ridges. The presence of scattered rocks indicates that they are scoured by bottom currents or have only recently been deposited, since pelagic sediments would otherwise bury them. The deposition of ice-rafted rocks must be a fairly random process without much relation to bottom topography, yet the depths of stations on ridges with rocks are always less than those of stations on ridges without rocks. Apparently, bottom currents have a scouring action on the more elevated features and a depositional action further down on the flanks. In some cases currents have seemingly winnowed away all of the fine sediment, leaving a residual gravel deposit analogous to "desert pavement" on land (Fig. 9). Where

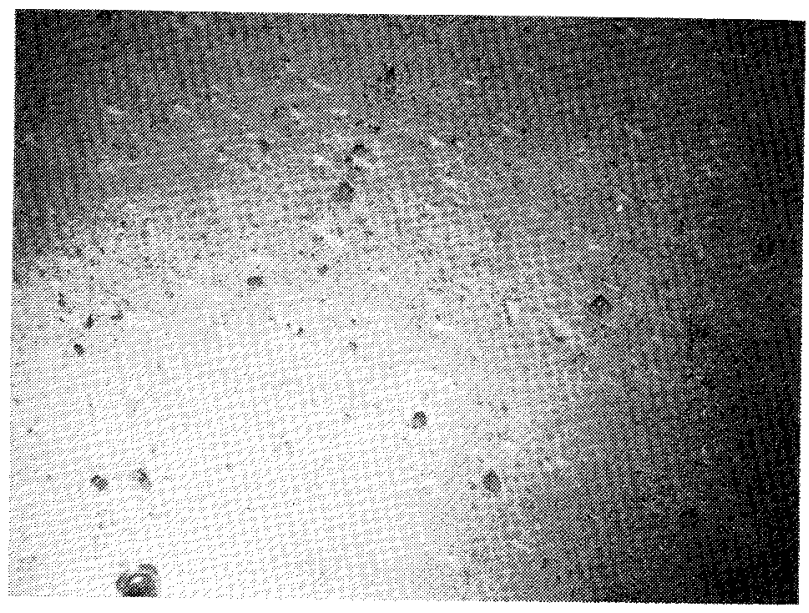

FIG. 12. Scattered rocks, rocks on northwest side of a knoll on the Mendeleyev Ridge. Sediment streamers in the lee of rocks indicate moderate bottom currents setting to the southwest magnetic. Location 1 in Fig. 11 , Sta. 67-22, 1,886 m. 

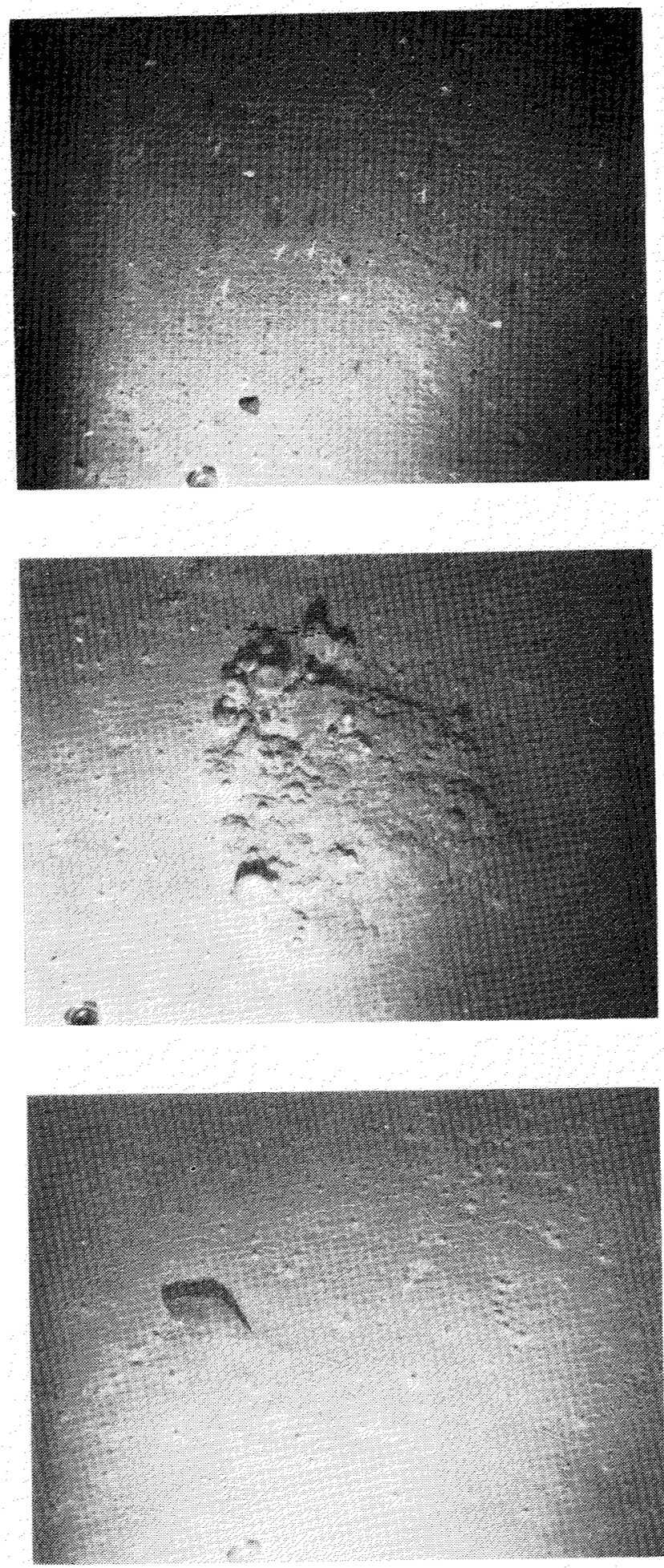

FIG. 13. Oriented sea lilies and sediment streamers indicating moderate bottom currents to the southwest on the crest of a knoll on the Mendeleyev Ridge. Location 2 in Fig. 11. Sta. 67-22, $1,749 \mathrm{~m}$.

FIG. 14. Rock outcrop with sponges and brittle stars near the crest of a knoll on the Mendeleyev Ridge. Loose sediment surrounds outcrop. Location 3 in Fig. 11. Sta. 67-22, 1,754 m.

FIG. 15. Ice-rafted rock, trails and sediment streamers on the southeast side of knoll on the Mendeleyev Ridge. Streamers suggest that the current sets southwest magnetic. Lack of scoured small rocks indicates predominant deposition. Location 4 in Fig. 11. Sta. $67-22,1,807 \mathrm{~m}$. 
currents are predominantly from one direction, they produce directional features such as the scour downstream from a boulder in Fig. 10. However, the currents are either not swift enough or the sediments are too fine for ripples to be produced, since none was noted.

Bottom characteristics change sharply over short distances in regions of rugged topography. Remarkable changes from scattered rocks to a field of crinoids, then to a rock outcrop and finally to soft smoothed sediment, all occurring within $300 \mathrm{~m}$., are shown in a striking series of photographs traversing a steep-sided knoll on the Mendeleyev Ridge (Figs. 12 to 15). The locations of these pictures are indicated in Fig. 11 by arrows on the precision sounding record made at the same time. Note that the wire depths are plotted in Fig. 11 at their appropriate locations on the sides of the knoll. These appear to fall below the bottom on the fathogram at locations 1 and 4 due to the width of the sounder beam and the sharpness of the peak which together produce a hyperbolic echo not truly representing the bottom. The bottom slopes at an angle of $45^{\circ}$ between locations 1 and 2. At the first location on the northwest side of the knoll (Fig. 12), scattered gravels with lee deposits indicate scouring by moderate bottom currents. The currents set to the southwest magnetic or west-southwest true. At the shallowest location (Fig. 13), a group of sea lilies are are all oriented in a common direction by bottom currents. Although it has been suggested that the lilies, being filter feeders, may face into the current, it seems likely from the evidence of sediment streamers in other frames at this station, that they are bent with the current. In the adjacent exposure (location 3), also on the crest, a rock outcrop with attached sponges is situated beside soft sediments (Fig. 14). The dark rock, apparently manganese encrusted, has a bumpy appearance. Round sponges and brittle stars cling to it. On the far side of the knoll, to the southeast, the smoothed muddy bottom has a few trails and an ice-rafted rock at location 4 (Fig. 15). The variety of bottom types on this knoll is attributed primarily to the action of bottom currents around rugged topography, eroding in some places and depositing in others.

Outcrops of indigenous rocks appear at only 2 stations, the one just discussed and station 67-3 (Fig. 16). Both stations were taken on the crests of steep knolls of the Mendeleyev Ridge. Although station 67-22 contained only one frame showing a rock outcrop (Fig. 13), sta. 67-3 contained many such frames (see for example, Fig. 16), alternating with frames showing loose sediments. Massive exposures of bedrock project through the surrounding unconsolidated sediments. Note the globular shapes of sponges and the white stalks of crinoids clinging to the rock for support in Fig. 16. No dredged samples of the rock were taken and its uneven surface could suggest such divergent rock types as volcanic basalts or solution-pitted limestones. The photographic information is inadequate to discriminate between them.

In summary, photographs of arctic submarine ridges generally show soft sediments studded with erratic rocks. Outcrops of indigenous rocks were noted at only 2 sites. Animals such as fish, crinoids, shrimp and sponges were observed at over 80 per cent of the ridge stations. However, animal tracks and trails are rare. Current lineations and scour in the lee of rocks are evidence of weak bottom currents. 


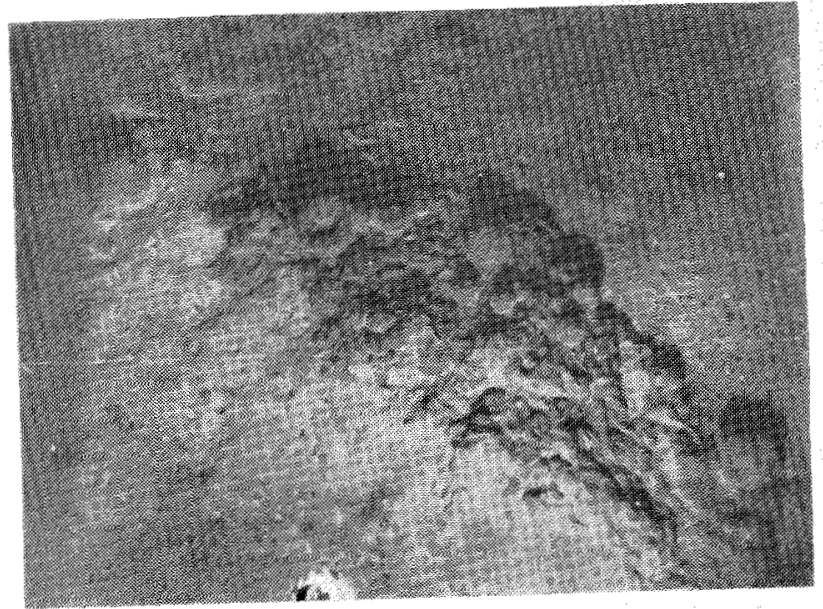

FIG. 16. Rock outcrop with attached sponges and crinoids at crest of knoll on the Mendeleyev Ridge. Sta. 67-3, $1,699 \mathrm{~m} ., 79^{\circ} 04^{\prime} \mathrm{N}$., $175^{\circ} 28^{\prime} \mathrm{W}$.

Since the Alpha Cordillera and Mendeleyev Ridge are believed to be extinct mid-oceanic ridges, it is of interest to compare these photographs with others from active ridges, such as those shown in Hersey (1967). The arctic ridge system is similar to mid-oceanic ridges in having both soft sediment and rock outcrops, animal life and lack of trails. However, manganese nodules, so prevalent on the foothills and flanks of mid-oceanic ridges elsewhere are not observed in arctic photographs, nor are talus blocks. Ripple marks are often found in the sediments of other mid-oceanic ridges but not in the Arctic Ocean. The photographic evidence is inadequate for a decision on the tectonic nature of the Alpha-Mendeleyev Ridge system and it can only be said that it does not rule out the possibility that this is a former mid-oceanic ridge.

\section{PLAINS AND RISES}

The level surface of the Canada Abyssal Plain covers the deepest part of the Canada Basin, an area of over $250,000 \mathrm{~km} .{ }^{2}$. Depth varies little from $3,780 \mathrm{~m}$. over the entire area. The bottom surface, with a slope of less than 1:1000, was evidently formed by turbidity currents which originated when sediment deposits on continental slopes became oversteepened and then slumped after being triggered by an event such as an earthquake. The mud suspension flowed down the continental slope and out across the basin floor depositing its load of fine-grained material evenly to form an extremely flat surface. Photographs from 17 abyssal plain stations present a monotonous similarity in appearance. Two typical views, Figs. 17 and 18, are not easy to distinguish from most of the remaining photographs taken on this plain. The clayey bottom is marked by a mosaic of interwoven tracks and trails together with small pits and mounds. The general appearance is level without the large mounds, deep pits or rocks found on ridges. In all stations, but one, on the Canada Abyssal Plain trails appeared in every exposure made at the station, while on the Alpha Cordillera none of the stations showed trails in every frame. Trails at many of the abyssal plain stations are similar and may be made by a single type of animal. The bottom has in most cases been worked and 


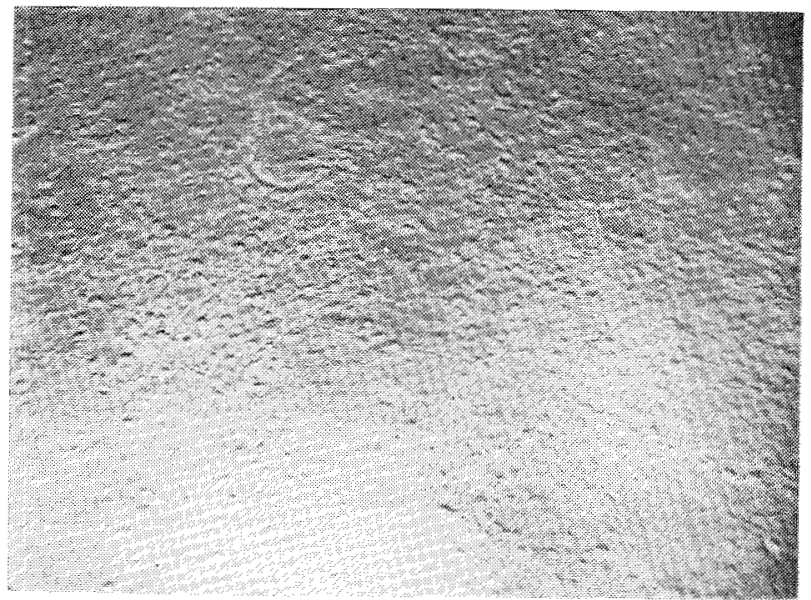

FIG. 17. Level floor of the Canada Abyssal Plain with abundance of tracks, trails and grooves as well as small mounds. Sta. 65-1, 3,703 m., $77^{\circ} 52^{\prime} \mathrm{N} ., 138^{\circ} 20^{\prime} \mathrm{W}$.

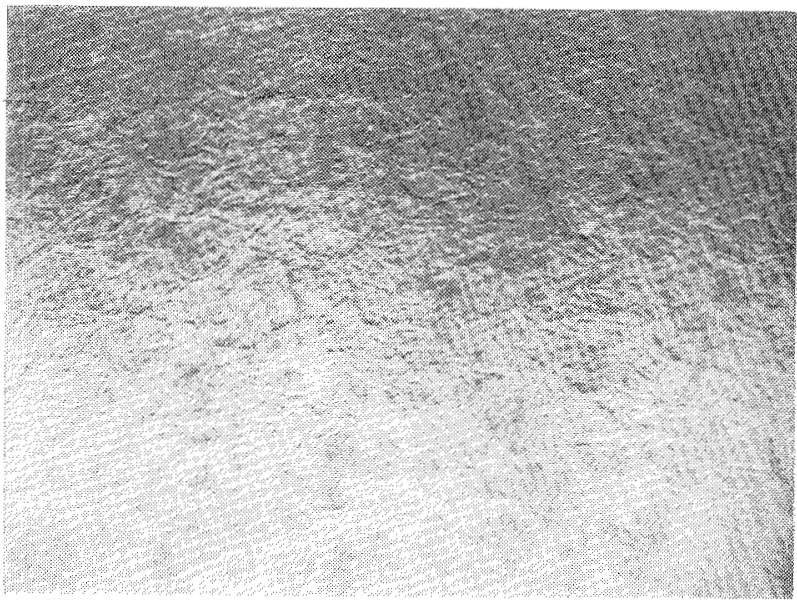

FIG. 18. Interwoven network of trails on the Canada Abyssal Plain. Sta. 66-6, 3,832 m., $75^{\circ} 56^{\prime} \mathrm{N}$., $151^{\circ} 38^{\prime} \mathrm{W}$.

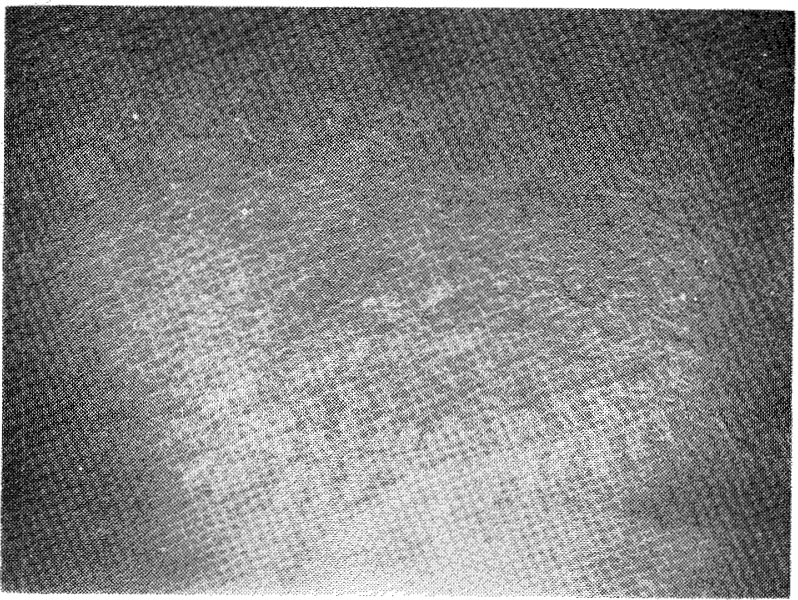

FIG. 19. Trails on the Canada Abyssal Plain. Note trail near bottom with V-shaped marks extending from a ridge of disturbed sediment. Sta. 66-3, 3,790 m., $75^{\circ} 18^{\prime} \mathrm{N} ., 146^{\circ} 25^{\prime} \mathrm{W}$. 
reworked by bottom feeders until it is a palimpsest of markings which leaves individual features unidentifiable. However, at one station (Fig. 19), fresh trails are clearer and are composed of a central ridge of disturbed sediment bordered by $\mathrm{V}$-shaped indentations. This type of trail is attributable to bottom-feeding fish which propel and support themselves on their pectoral fins, scooping up mud with their mouths as they move. The paucity of visible animals on the Canada Abyssal Plain also contrasts with the ridges; this in spite of the abundance of trails on this plain. Animals appeared at only 35 per cent of the Canada Abyssal Plain stations whereas they appeared at 85 per cent of the Alpha Cordillera stations.

The small Northwind Abyssal Plain, perched between the Northwind Ridge and the Chukchi Plateau at a depth of $2,100 \mathrm{~m}$., covers an area of about 10,000 $\mathrm{km} .^{2}$. Its soft sediments are also marked by trails and are devoid of rocks. The trails on the Northwind Abyssal Plain are different from those on the Canada Abyssal Plain, consisting of a wide furrow bordered by small ridges (Fig. 20).
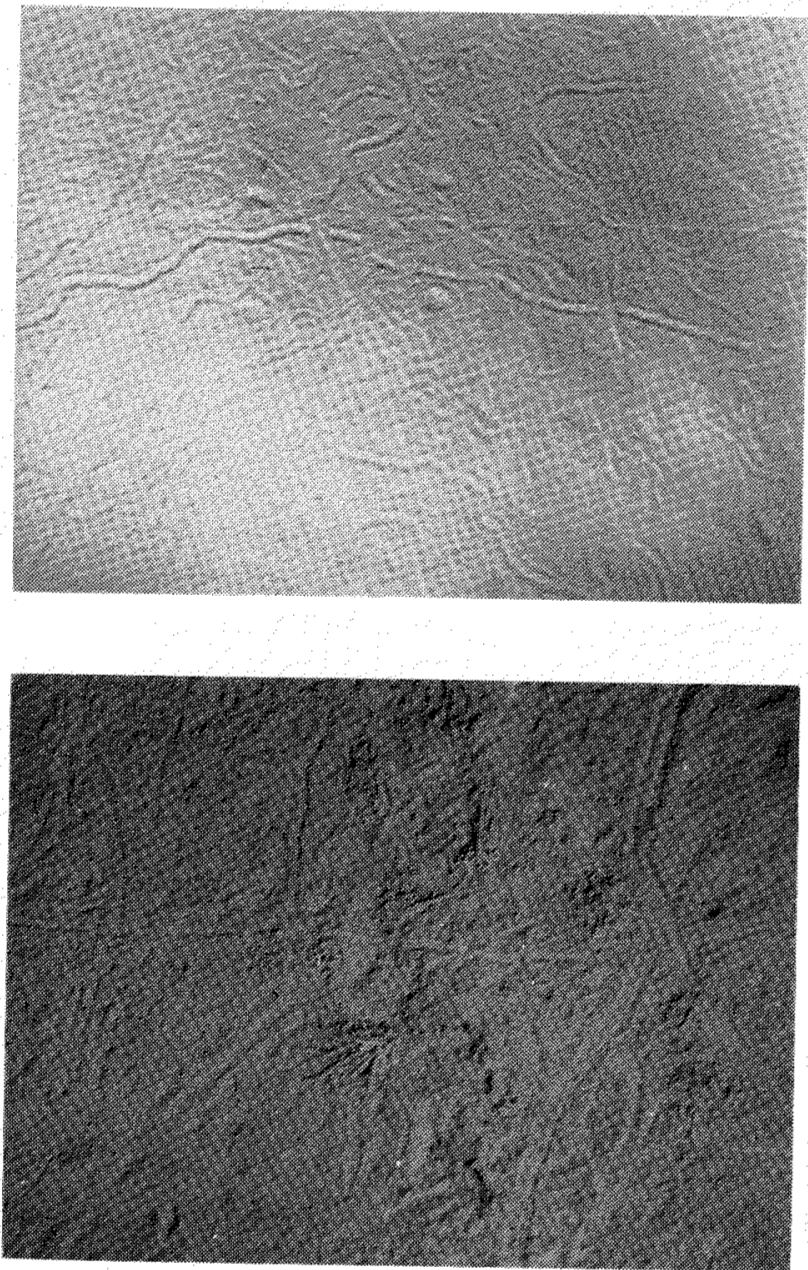

FIG. 20. Tracks and trails on muddy bottom of the Northwind Abyssal Plain. Sta. 66-21, $2,084 \mathrm{~m}$., $75^{\circ} 43^{\prime} \mathrm{N}$., $160^{\circ} 28^{\prime} \mathrm{W}$.

FIG. 21. Close-up photograph showing fecal pellets and trails on the Mendeleyev Ridge. Camera face $35 \mathrm{~cm}$. from bottom. Photograph represents an area of about $18 \times 26 \mathrm{~cm}$.; $2,797 \mathrm{~m}$., $79^{\circ} 36^{\prime} \mathrm{N}$., $172^{\circ} 32^{\prime} \mathrm{W}$. 
Another perched plain, the Mendeleyev Plain, occupies the northwestern arm of the Canada Basin. Sediments have apparently been impounded there by a bedrock dam extending northward from the Chukchi Plateau. Average depth is about $3,260 \mathrm{~m}$. but it is not certain that the gradient is the required 1:1000 or less to classify it as an abyssal plain. The features on this plain seem more closely allied to those on the Alpha Cordillera than to those on the Canada Abyssal Plain on the basis of the characteristics in Table 1.

The single station on the continental rise closely resembles the Canada Abyssal Plain in characteristics. The continental rise grades smoothly into the Canada Abyssal Plain and this station is almost on the border separating the two features.

\section{CLOSE-UP PHOTOGRAPHS}

In order to examine details of the bottom more closely, a tripod camera, developed originally as a current meter device, was employed. The camera was mounted, with the lens pointing straight downward, at the apex of a tripod resting on the bottom. The camera was adjusted so that its window was only $35 \mathrm{~cm}$. off the bottom for Fig. 21 which was taken on the Mendeleyev Ridge. The two intersecting trails on the right of this photograph appear to have been made by different animals. The lower one consists of a central furrow with fine tracks along either side. The upper one has a median ridge bordered by grooves. Fecal pellets occur in piles. The pile of pellets near the centre has a rough-textured patch to its right, appearing as though the animal stayed at that spot for some time ingesting mud and excreting pellets. Bottom feeders must ingest and discharge a large amount of mud to extract even a small amount of nourishment.

\section{DISCUSSION}

The strong contrasts in bottom type between the ridges and abyssal plains must reflect differing sedimentary processes. Pelagic sedimentation, the slow rain of terrestrial and organic debris downward through the water column, must be similar over the entire basin considered here. Pelagic sedimentation has been at the slow rate of $1 \frac{1}{2} \mathrm{~mm} . / 1000$ years over the past 70,000 years (Hunkins and Kutschale 1967; Ku and Broecker 1967). The ice drift pattern shows little relation to topography and the deposition of erratic rocks would also be expected to be similar over both plains and ridges. Turbidity current deposits, however, are unique to abyssal plains and provide an explanation for the lack of rocks there. The rocks on plains would be buried by repeated floodings of turbidity deposits while on ridges the slow accumulation of pelagic sediments would require thousands of years to bury a boulder.

Bottom current regimes differ and may also account for the differences in bottom photographs on plains and ridges. A nepheloid layer of very fine suspended material is observed only over Arctic Ocean ridges and not over plains (Hunkins et al. 1969). This material must be kept in suspension by turbulence associated with bottom currents over the ridges. A few direct measurements of bottom currents on the Mendeleyev Ridge also support the idea of moderate 
(less than $5 \mathrm{~cm} . / \mathrm{sec}$.) bottom currents over the ridges and almost none on the Canada Abyssal Plain. These bottom currents evidently smooth and obliterate trails fairly rapidly so that even though more living animals are present on the ridges their markings are not as abundant as on the plain. The tracks on plains may be preserved for long periods in the absence of currents, until a new turbidity current finally wipes the slate clean. This probably happens at infrequent intervals. On the basis of radiocarbon dating, the last turbidity current in the Canada Abyssal Plain occurred 1,500 years ago (Hunkins and Kutschale 1967).

\section{ACKNOWLEDGEMENTS}

The assistance of John K. Hall in camera operations at T-3 is gratefully acknowledged.

Without the logistic support of the Naval Arctic Research Laboratory at Barrow, Alaska, under the direction of Dr. Max Brewer, this research could not have been accomplished. The work was supported by the Office of Naval Research under Contract N00014-67-A-0108-0016.

\section{REFERENCES}

Beal, M. A. 1968. Bathymetry and structure of the Arctic Ocean. Unpublished Ph.D. thesis, Oregon State University. 203 pp.

CARSOLA, A. J., R. L. FISHER, C. J. SHIPEK and G. SHUMWAY. 1961. Bathymetry of the Beaufort Sea. In: G. O. Raasch, editor. Geology of the Arctic. Proceedings of the International Symposium on Arctic Geology, 1960. Vol. 1. pp. 678-89.

CROMIE, W. J. 1961. Preliminary results of investigations on arctic drift station Charlie. In: G. O. Raasch, editor. Geology of the Arctic. Proceedings of the International Symposium on Arctic Geology, 1960. Vol 1. pp. 690-708.

EWING, M., K. HUNKINS and E. THORNDIKE. 1969. Some unusual photographs in the Arctic Ocean. Marine Technology Society Journal, 3: 41-44.

HERSEY, J. B. 1967. Deep-sea photography. Baltimore: Johns Hopkins Press. 310 pp.

HUNKINS, K. 1968. Geomorphic provinces of the Arctic Ocean. In: J. Sater, editor. Arctic Drifting Stations. Montreal: Arctic Institute of North America, pp. 365-76.

HUNKINS, K., M. EWING, B. HEEZEN and R. MENZIES. 1960. Biological and geological observations on the first photographs of the Arctic Ocean deep-sea floor. Limnology and Oceanography, 5: 154-61.

HUNKINS, K. and H. KUTSCHALE. 1967. Quaternary sedimentation in the Arctic ocean. In: M. Sears, Progress in Oceanography, Vol. IV. Oxford: Pergamon Press, pp. 89-94.

HUNKINS, K., E. THORNDIKE and G. MATHIEU. 1969. Nepheloid layers and bottom currents in the Arctic Ocean. Journal of Geophysical Research, 74: 6995-7008.

KU, T. L. and W. BROECKER. 1967. Rates of sedimentation in the Arctic Ocean. In: M. Sears, Progress in Oceanography, Vol. IV. Oxford: Pergamon Press, pp. 95-104.

SCHWARZACHER, W. and K. HUNKINS. 1961. Dredged gravels from the Central Arctic Ocean. In: G. O. Raasch, editor. Geology of the Arctic. Proceedings of the International Symposium on Arctic Geology, 1960. Vol. 1. pp. 666-71.

THORNDIKE, E. 1959. Deep-sea cameras of the Lamont Observatory, Deep-Sea Research, 5: 234-37.

1963. A suspended-drop current meter. Deep-Sea Research, 10: 263-67. 